\title{
ІНФОРМАЦІЙНА СИСТЕМА ПЛАНУВАННЯ, ОБЛІКУ, МОНІТОРИНГУ ТА УПРАВЛІННЯ ІНОВАЦІЙНОЮ ДІЯЛЬНІСТЮ В СФЕРІ ОХОРОНИ ЗДОРОВ'Я УКРАЇНИ
}

\author{
А. Є. Горбань, М. Л. Кочина ${ }^{1}$ \\ Украӥнський центр наукової медичної інфрормації \\ та патентно-ліцензійної роботи МОЗ України \\ ${ }^{1}$ Харківська медична академія післядипломної освіти
}

\begin{abstract}
Представлено наукове обґрунтування розробки та побудови автоматизованої інсрормаційної системи обліку, моніторингу та прогнозування ефективності інноваційної діяльності. Для реалізації функцій реєстрації, моніторингу та прогнозування інноваційної ефективності науково-дослідних робіт обрано дворівневу клієнт-серверну архітектуру інфрормаційної системи. Для захисту інформації та розмежування доступу користувачів до окремих ресурсів інформаційної системи обрано модель рольового доступу. При розробці додатків було використано програмний інтерфейс Microsoft WinAPI та мова програмування C++. Для створення графічного інтерфейсу користувача використано технологію Windows Forms, для вирішення завдання об'єктно-реляційного відображення даних у додатку використано якісне ORM рішення для платсорми .NET Framework технологія ADO.NET Entity Framework.
\end{abstract}

Ключові слова: автоматизована інформаційна система, інноваційна діяльність, моніторинг, прогнозування

\section{ИНФОРМАЦИОННАЯ СИСТЕМА ПЛАНИРОВАНИЯ, УЧЕТА, МОНИТОРИНГА И УПРАВЛЕНИЯ ИННОВАЦИОННОЙ ДЕЯТЕЛЬНОСТЬЮ В СФЕРЕ ЗДРАВООХРАНЕНИЯ УКРАИНЫ}

\author{
Украинский центр научной медицинской инфрормации \\ и патентно-лицензионной работы МЗ Украины \\ ${ }^{1}$ Харьковская медицинская академия последипломного образования
}

А. Е. Горбань, М. Л. Кочина

\begin{abstract}
Ежегодно научными коллективами организаций, учреждений и предприятий из ссеры управления Министерства здравоохранения (МЗ) Украины выполняется более 200 научно-исследовательских работ (НИР), по результатам которых создается инновационная продукция (новый способ, методика, соединение, устройство и тому подобное). Рост объемов медицинской информации, получаемой при выполнении НИР, приводит к необходимости ускорения ее обработки и передачи субъектам инновационной деятельности. Эту проблему можно эффективно решить путем использования автоматизированных информационных систем. Своевременный анализ поступающей информации, особенно на этапе планирования ниР, и прогнозирование ее эффективности позволяет избежать ошибок в принятии управленческих решений. В статье представлено научное обоснование разработки и создания автоматизированной информационной системы учета, мониторинга и прогнозирования эффективности инновационной деятельности. Для реализации функций регистрации, мониторинга и прогнозирования инновационной эффективности НИР избрана двухуровневая клиент-серверная архитектура информационной системы. Для защиты информации и разграничения доступа пользователей к отдельным ресурсам избрана модель ролевого доступа. При разработке дополнений были использованы программный интерфейс Microsoft WinAPI и язык программирования C++. Для создания графического интерфейса пользователя использована технология Windows Forms, для решения задания объектно-реляционного отображения данных в приложении использовано качественное ORM решение для платформы .NET Framework технология ADO.NET Entity Framework.
\end{abstract}

Ключевые слова: автоматизированная информационная система, инновационная деятельность, мониторинг, прогнозирование.

$\overline{(\mathcal{C} \text { А. Є. Горбань, М. Л. Кочина }}$ 


\title{
INFORMATION SYSTEM FOR PLANNING, ACCOUNTING, MONITORING AND MANAGEMENT OF INNOVATION IN THE UKRAINIAN HEALTH CARE SPHERE
}

\author{
A. E. Gorban, M. L. Kochyna ${ }^{1}$ \\ Ukrainian Centre of Scientific Medical Information and Patent-Licence Provision \\ Ministry of Public Health of Ukraine
}

${ }^{1}$ Kharkiv Medical Academy of Postgraduate Education

\begin{abstract}
Each year, research teams of organizations, institutions and enterprises from the sphere of the Ministry of Public Health (MPH) of Ukraine carried out more than 200 scientific research works (SRW), the results of which creates innovative products (new method, a technique, a compound device, and the like). Growth in the medical information obtained in the performance of SRW results in the need to speed up the processing and transfer of innovation activity agents. This problem can be effectively addressed through the use of automated information systems. Timely analysis of the incoming information, particularly at the planning stage of SRW, and forecasting its effectiveness permit to avoid mistakes in management decisions. In this regard, relevant and timely is the development of automated information systems and modern information technologies for collecting, processing and analyzing information.

The article presents the scientific basis of development and the creation of an automated information system for recording, monitoring and forecasting of the effectiveness of innovation. The basic principles to be met by the developed system are systemic, development, interoperability, standardization and efficiency, data security and reliability, agility, visibility and intuitive user experience, ease of use and minimal sufficient of information support.

To implement the functions of registration, monitoring and forecasting of the innovative effectiveness of SRW elected two-tier client server architecture of the information system. To protect data and user access to specific resources, role-based access model chosen. In the development of add-ons have been used Microsoft WinAPI programming interface and programming language $\mathrm{C}++$.

The software does not require installation on the user's computer and then run the standard can be used to fill in the electronic «questionnaire of SRW». To implement the functions of storing and processing questionnaires of SRW, data analysis, and generate corresponding reports developed software option «SRW reports» on the software platform Microsoft .Net Framework programming language $\mathrm{C} \#$. To create a graphical user interface used by the technology Windows Forms, to solve the task of object-relational mapping data used in the application quality ORM solution for the .NET Framework technology ADO.NET Entity Framework.
\end{abstract}

Key words: automated information system, innovation, monitoring, forecasting.

Вступ. Кожного року науковими колективами організацій, установ і підприємств зі сфери управління Міністерства охорони здоров'я (MO3) України виконується більше 200 науково-дослідних робіт (НДР), за результатами яких створюється інноваційна продукція (новій спосіб, методика, сполука, пристрій, тощо), що оформлюється в певні інформаційні об'єкти. Практичне використання цих інформаційних об'єктів слід вважати обов'язковою умовою для забезпечення подальшого впровадженням інноваційних розробок. Впровадження результатів виконання НДР в охорону здоров'я дозволяє істотно поліпшити структуру медичного обслуговування населення та якість надання медичної допомоги. За умови високої конкурентоздатності отриманих наукових результатів процес їх впровадження в сферу охорони здоров'я України відповідає законодавчому визначенню поняття інноваційної діяльності [1]. В процесі інноваційної діяльності беруть участь організації розробники інноваційного продукції та організації, які використовують (впроваджують) цю продукцію. Обидва види організацій, що орієнтовані на створення та впровадження наукоємної конкурентоспроможної продукції, називаються інноваційними структурами.

В сфері охорони здоров'я України до складу інноваційних структур відносяться наукові колективи, що організаційно об'єднані в науково-дослідних установах, діяльність яких має медичне спрямування, та вищі медичні (фармацевтичний) навчальні заклади, з іншого боку - заклади охорони здоров'я незалежно від спеціалізації та відповідності рівню надання медичної допомоги. Для забезпечення ефективної роботи інноваційних структур у медичній сфері потрібен рух сучасної медичної інформації між суб’ єктами відносин [2].

3 кожним роком зростають обсяги медичної інформації, що потребує прискорення її оброблення та забезпечення швидкості їі руху між суб'єктами інноваційних структур. Збільшується обсяг матеріалів, що необхідно досліджувати управлінцям сфери охорони здоров'я для прогнозування конкурентоспроможності очікуваного наукового результату та інноваційного продукту. Зростає вірогідність припущення помилок при прийнятті управлінських рішень щодо планування НДР. 
У сучасному світі при виникненні проблем зі збільшенням обсягів інформації, яка потребує дослідження та з метою мінімізації ризиків прийняття помилкових управлінських рішень, застосовують інструментарій автоматизованої обробки інформації (інформаційні системи - Системи) та математичного прогнозування.

Мета роботи: наукове обґрунтування розробки та побудови автоматизованої інформаційної системи обліку, моніторингу та прогнозування ефективності інноваційної діяльності.

Матеріал і методи дослідження. До об’єктів дослідження віднесено законодавчі акти та нормативні документи галузевого рівня, оформлені засоби наукової комунікації та звітні результати про використання наукової продукції в сфері охорони здоров'я України.

Розробка структурних компонентів Системи виконана з використанням програми Microsoft Visio 2010.

Результати та їх обговорення. При виконанні НДР, як фундаментальних, так і прикладних, отримуються інновації, що можуть бути оформлені у вигляді наукових результатів та наукової продукції (рис.1). робіт, які плануються, обліку та моніторингу інновацій, що впроваджуються в охорону здоров'я потребують створення автоматизованої інформаційної системи. Ця система дозволить створити умови для підтримки прийняття управлінських рішень на всіх етапах розробки та впровадження інновацій.

Проведені дослідження наявних інформаційних систем та принципів їх побудови дозволили сформулювати основні принципи, яким повинна відповідати спеціалізована інформаційна система планування, обліку та моніторингу інноваційної медичної інформації. До цих принципів належать принципи: системності, розвитку, сумісності, стандартизації та ефективності, безпеки даних і надійності тощо [2].

3 урахуванням сформульованих принципів було розроблено функціональну схему інформаційної системи обліку та моніторингу інноваційної діяльності (рис. 1, а). База даних (БД) формується з використанням інформації про наукові колективи та установи, етапи планування, виконання та завершення НДР, обробка якої дозволяє розробити моделі прогнозу ефективності виконання НДР, створювати аналітичні огляди та звіти, підтримува-

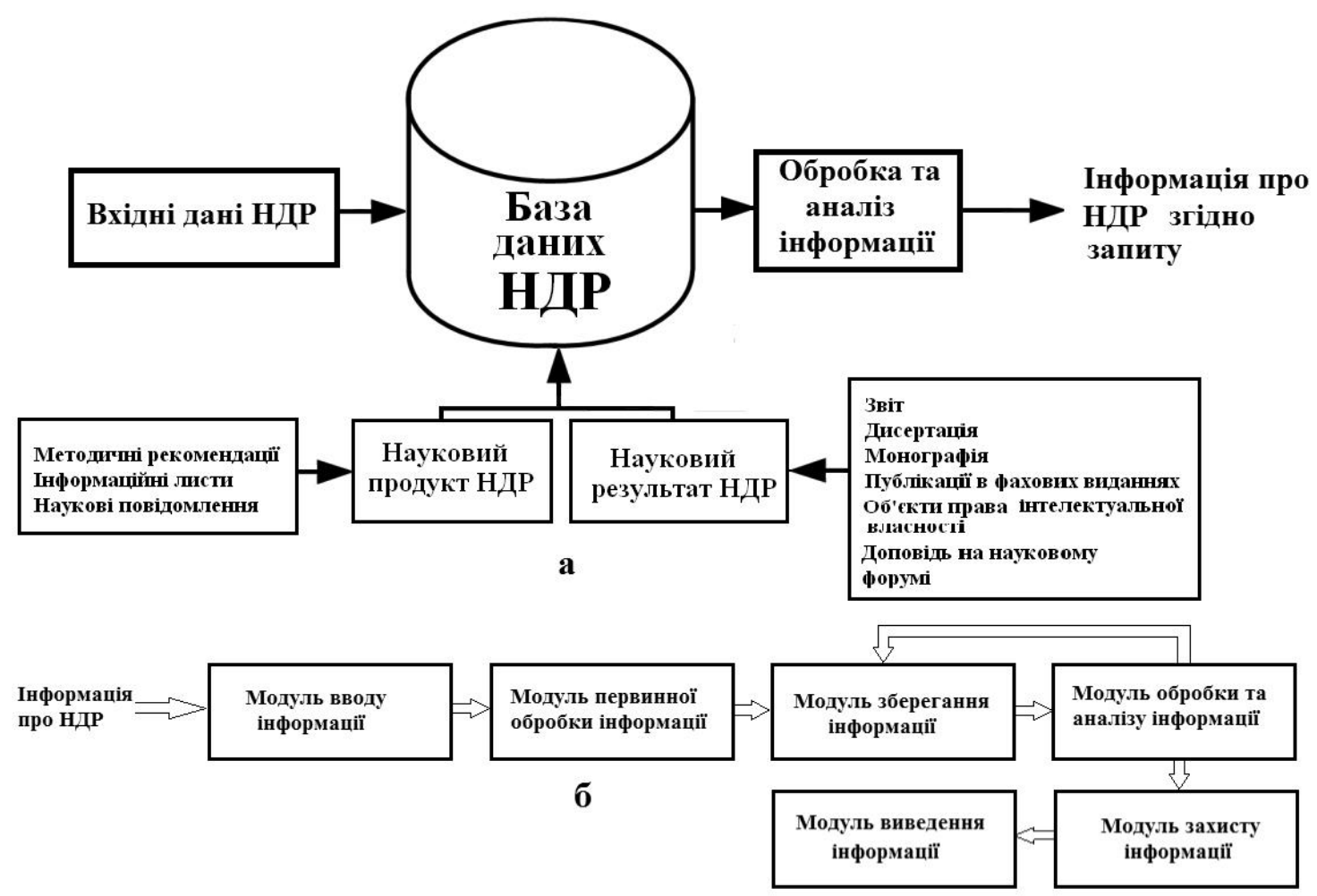

Рис. 1. Функціональна (а) та структурна (б) схеми інформаційної системи обліку, моніторингу та прогнозування ефективності інноваційної діяльності

Постійно зростаюча кількість наукових результатів виконання НДР, необхідність у проведенні об’єктивної експертизи інноваційної перспективи ти управлінські рішення в сфері охорони здоров'я. Структурно інформаційна система може бути реалізована у вигляді набору модулів, кожний 
3 яких виконує відповідні функції (рис. 1, б). Запропонована структурна схема включає модулі вводу, обробки, зберігання, аналізу, захисту і виведення інформації, та дозволяє зберігати необхідний набір текстових, числових і графічних даних про результати інноваційної діяльності в сфері охорони здоров'я, представити їх у зручному, структурованому вигляді з можливістю швидкого доступу до потрібних даних для їх відображення, проведення аналізу, класифікації, розрахунку показників та визначення ефективності виконання НДР.

Перший модуль запропонованої інформаційної системи призначений для введення інформації, що може бути здійснено різними способами, як безпосередньо шляхом комп'ютерного набору з паперового носія, так і з використанням електронних форм. Структура форми, що базується на використанні автономних програмних додатків, схематично показана на рис. 2.
За допомогою програмних модулів, що підключаються, відповідальна особа Головної установи може проаналізувати отримані дані і сформувати відповідні звіти.

Форма автономних додатків в умовах наявних технічних ресурсів є оптимальнім рішенням реалізації Системи. Головною перевагою такого рішення $\epsilon$ максимальна незалежність окремих елементів системи, можливість оперативного внесення змін в будь-які процеси.

Створення інформаційних комп'ютерних систем рівня підприємства вимагає якісного планування, глибокого аналізу і моделювання. Модель бізнес-процесів розробленої Системи представлена на рис. 3.

Для формалізації бізнес-процесів, які мають місце при моніторингу інноваційної медичної інформації, проведене моделювання з використанням стандарту IDEF0. Зліва, стрілки що входять, представляють потоки даних які входять в дану

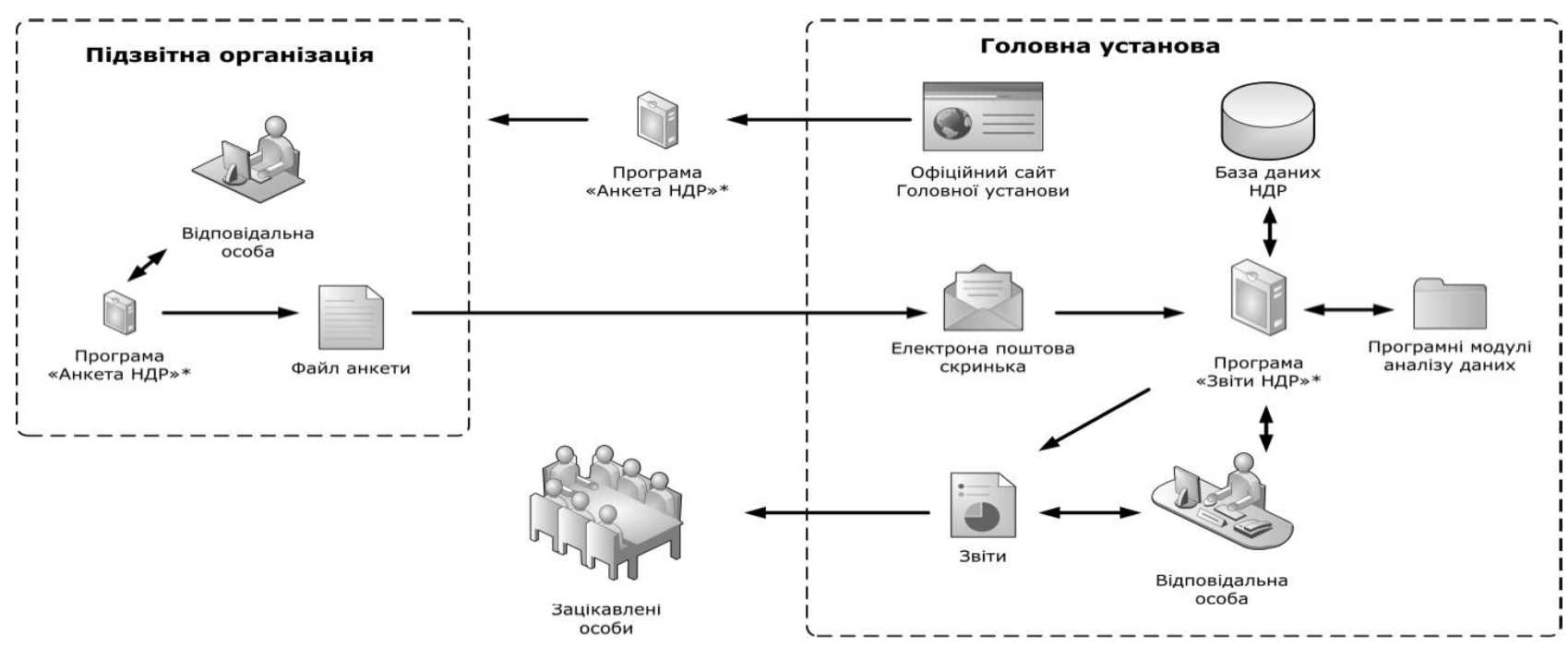

Рис. 2. Форма автономних програмних додатків

При цьому способі введення інформації відповідальна особа підзвітної організації з офіційного сайту Головної установи завантажує спеціальний додаток (умовна програма «Анкета НДР»). Він використовується для формування файлів - анкет НДР у форматі, який дозволяє передавати інформацію за допомогою електронної або традиційної пошти (на електронному носії). Після надходження звіту на спеціальну електрону адресу Головної установи інша відповідальна особа використовує спеціальний додаток (умовна програма «Звіти НДР») для завантаження до бази даних отриманих звітів для збереження та подальшої обробки. модель. Праворуч представлені результати виконання бізнес-процесу. Стрілки зверху є керуючими об'єктами моделі і представлені керуючими документами. Модель відображає структуру та ієрархію бізнес-процесу, деталі виконання, виконавців і послідовність документообігу.

До вхідних даних відносяться: дані анкет НДР; дані експертної оцінки НДР. До вихідних даних відносяться: звіти, прогнози.

Архітектура сучасних інформаційних систем, як правило, базується на класичних дворівневих або трирівневих клієнт-серверних архітектурах $[3,4]$. Сервер баз даних (БД) забезпечує централізоване, безпечне і надійне зберігання інформації. 


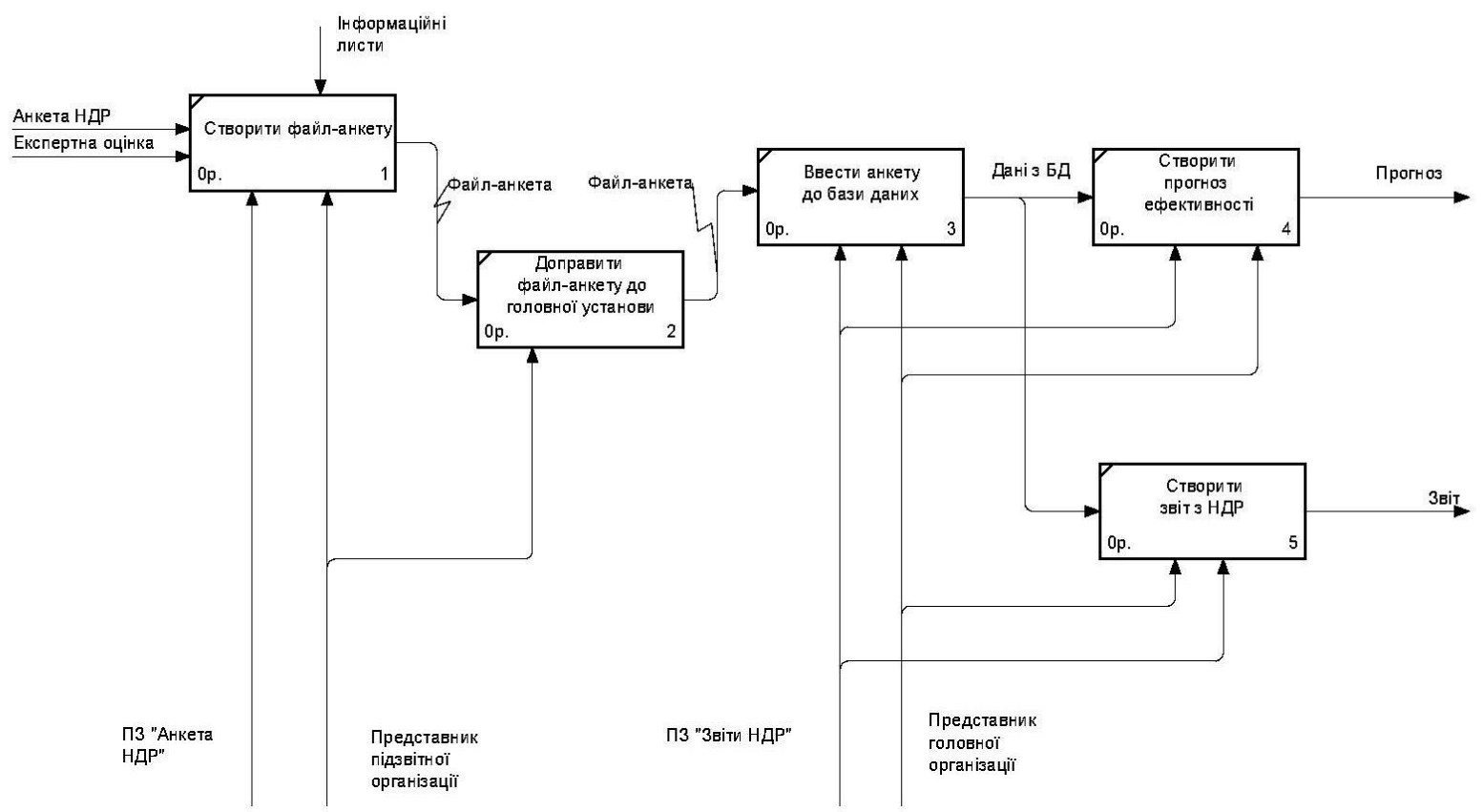

Рис. 3. Модель бізнес-процесів медичної інформаційної системи

Користувачі на своїх автоматизованих робочих місцях (АРМ) отримують доступ к інформації через локальну мережу передачі даних. Користувальницький додаток, запущений на АРМ, реалізує клієнтську частину інформаційної системи. У дворівневій архітектурі відбувається безпосередня взаємодія сервера та АРМ, а в трирівневій архітектурі між ними встановлюється додатковий сервер додатків, який дозволяє зменшити навантаження на БД і канал зв'язку. Аналіз контрольних цифр можливого робочого навантаження на інформаційну систему, що розробляється, дозволив встановити, що для реалізації функцій реєстрації, моніторингу та прогнозування ефективності впровадження інноваційної медичної інформації достатньо дворівневої клієнт-серверної архітектури. Така система буде мати достатню для вирішення поставлених завдань надійність і швидкість обчислень.

Для розмежування доступу користувачів до окремих ресурсів інформаційної системи обрано модель рольового доступу. При реалізації такої моделі спектр доступної інформації для користувачів системи групуються з урахуванням специфіки виконуваних ними посадових обов'язків, що і утворюють ролі. На основі проведеного моделювання бізнес-процесів Системи (рис. 3.) було виділено три користувальницькі ролі. Роль “Адміністратор" повинна мати достатній обсяг прав для проведення первинної установки і налаштування програмного забезпечення на робочих місцях, а також подальшої підтримки працездатності всієї системи. При цьому слід обмежити для цієї ролі можливості перегляду і редагування даних для усунення спроб внесення навмисних спотворень інформації в Системі. Роль «Аналітик» повинна мати достатній рівень доступу до інформації в Системі для якісної обробки та аналізу збережених даних. Для забезпечення об’єктивності проведення аналізу дані повинні бути деперсоналізовані, а можливість внесення змін у вихідну інформацію виключена. Роль «Користувач» повинна мати достатній обсяг прав для виконання адміністративних завдань: завантаження файлів-анкет в базу даних, перегляд та верифікація отриманих даних, надання інформаційної підтримки підзвітним організаціям. Можливість копіювання або видалення даних, а так само їх аналіз не повинен бути доступний користувачам $з$ такою роллю, так як це може призвести до навмисного спотворення, «підгонці» інформації.

Моделювання бізнес-процесів інформаційної системи дозволило розробити схему бази даних, представлену на рис. 4, що складається 3 пов'язаних таблиць. Таблиця user_action зберігає дані про дії користувачів Системи; таблиця report_item зберігає анкетні дані НДР; таблиці result i product зберігають дані про отримані при виконанні НДР наукові результати і наукові продукти; таблиця ехреrt зберігає дані експертної оцінки НДР; таблиця finance зберігає дані про фінансування НДР; таблиця link зберігає дані про зв’язок між НДР; таблиця org_info зберігає дані про підзвітні організації. 


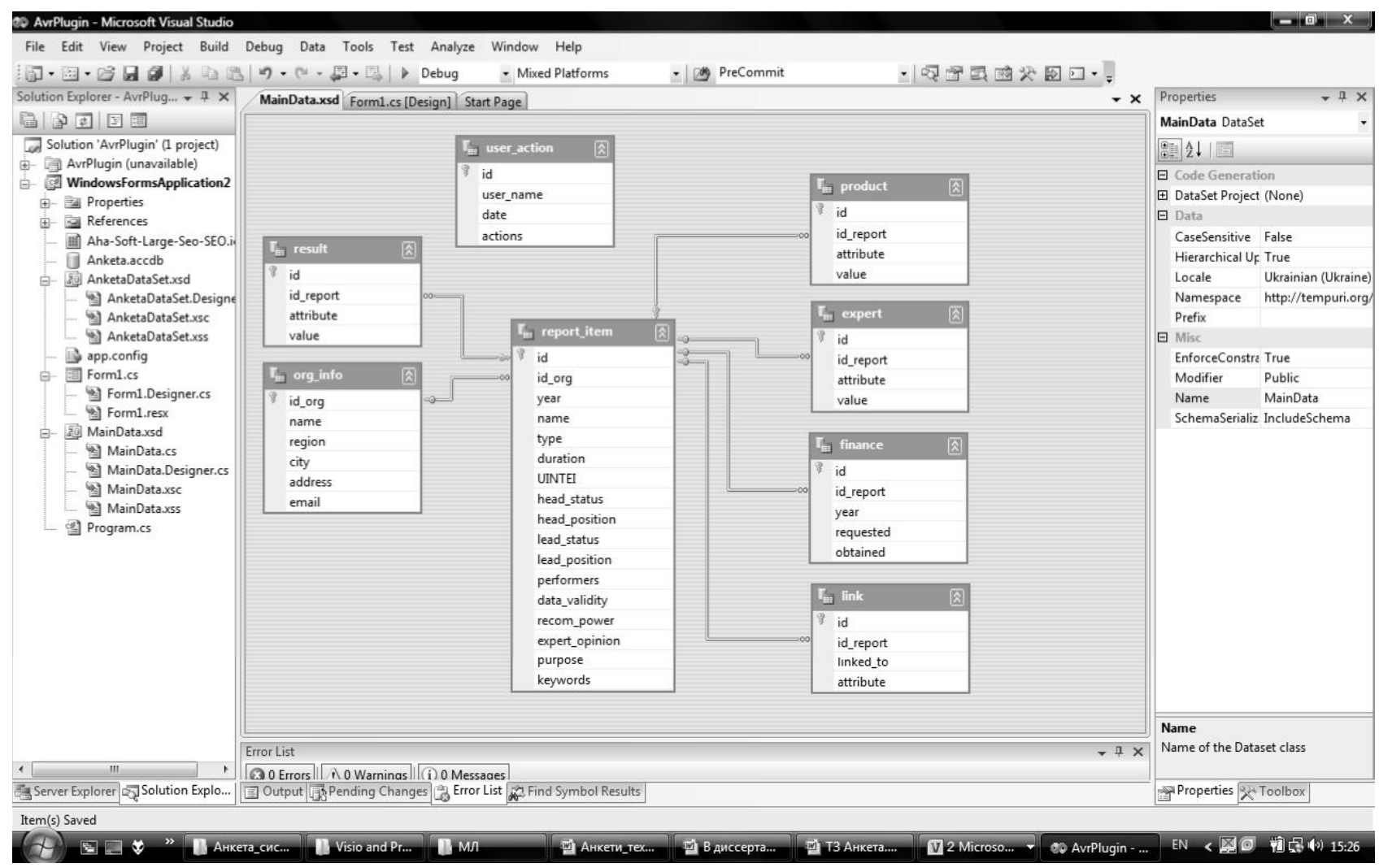

Рис. 4. Структура бази даних

Більшість сучасних інформаційних систем, орієнтованих на роботу з БД, використовують реляційні системи управління базами даних (РСУБД). Для управління даними в Системі обрана РСУБД PostgreSQL. Вона має достатній набор реалізованих функцій і порівнянна з кращими комерційними СУБД класу Oracle Database або Microsoft SQL Server. Програмне забезпечення РСУБД може бути запущена на більшості UNIX-подібних OC, а також Microsoft Windows. Система PostgreSQL використовує модель клієнт / сервер, де зазвичай клієнт і сервер знаходяться на фізично різних комп'ютерах і з'єднуються за допомогою комп’ютерної мережі по протоколу TCP / IP.

Для формування файлів - анкет НДР в підзвітних організаціях створений програмний додаток «Анкета НДР», що може бути вільно розповсюджений через WEB-сайт Головної установи. Такий підхід дозволяє значно спростити і прискорити процеси подачі інформації. Підготовлені таким чином файли - анкети після доставки в Головну установу можуть бути автоматично внесені в БД, виключаючи етап ручної обробки. При розробці цього програмного забезпечення реалізовані наступні принципи: динамічності, наочності та інтуїтивного сприйняття користувачем, зручності у використанні та мінімального достатнього інформаційного забезпечення.

Оскільки більшість сучасних користувачів ПК віддають перевагу роботі в середовищі OC Microsoft Windows, то для реалізації принципів наочності та інтуїтивного сприйняття користувачем, зручності у використанні оптимальним рішенням є створення програми з використанням тільки вбудованих функцій цієї ОС. Для цього при розробці додатку «Анкета НДР» використовується лише програмний інтерфейс Microsoft WinAPI і мова програмування C++. Створений з його використанням програмний додаток складається з єдиного виконуваного файлу і не вимагає для своєї роботи встановлення додаткових компонентів, на відміну від додатків що розроблені 3 використанням платформ Microsoft .NET Framework, Oracle Java, Digia Qt тощо.

Програмне забезпечення «Анкета НДР» не потребує встановлення на комп’ютер користувача i після стандартного запуску можна одразу перейти до заповнення електронної анкети, що є стилізованою копією паперової форми (рис. 5). Після заповнення всіх полів електронної анкети з'являється можливість зберегти її у вигляді текстового файлу 
зі спеціальним форматуванням. Цей файл зручним способом (переважно електронною поштою) доставляється в Головну організацію.
Для реалізації функцій збереження та обробки файлів - анкет НДР, аналізу отриманих даних і формувати відповідних звітів створений програмний

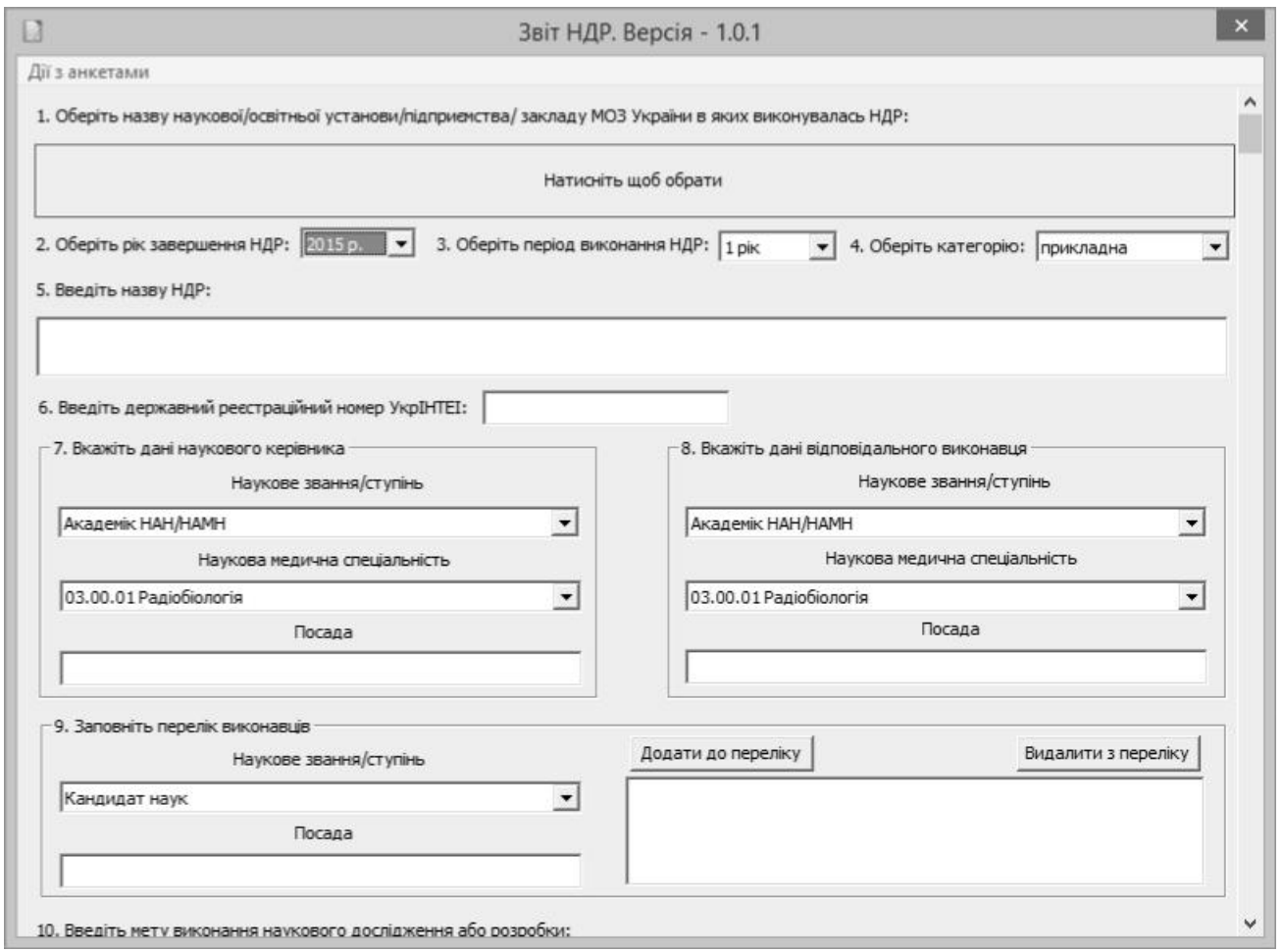

Рис. 5. Вікно введення даних НДР ПЗ «Звіт НДР. Версія - 1.0.1»

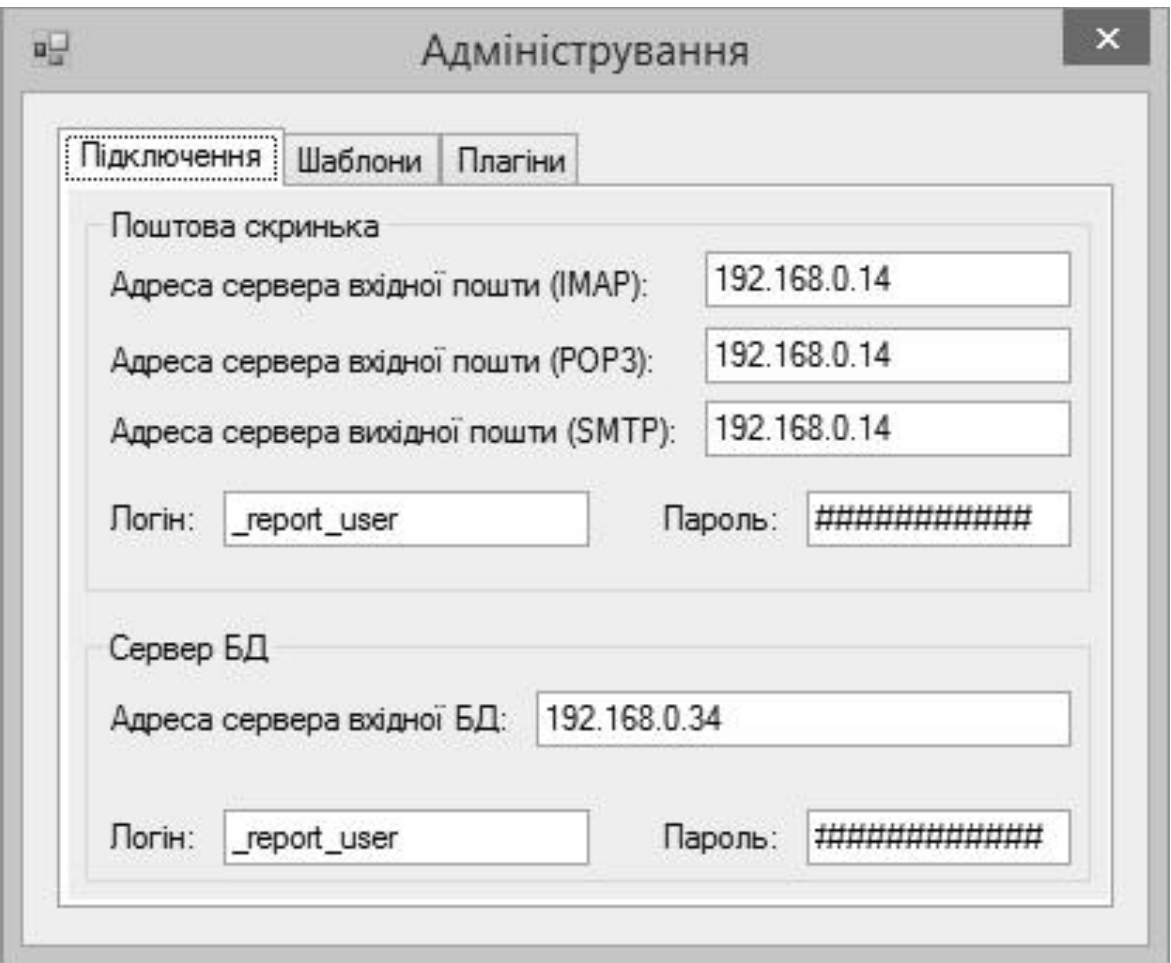

Рис. 6. Головна форма інтерфейсу адміністратора додатку «Звіти НДР» 


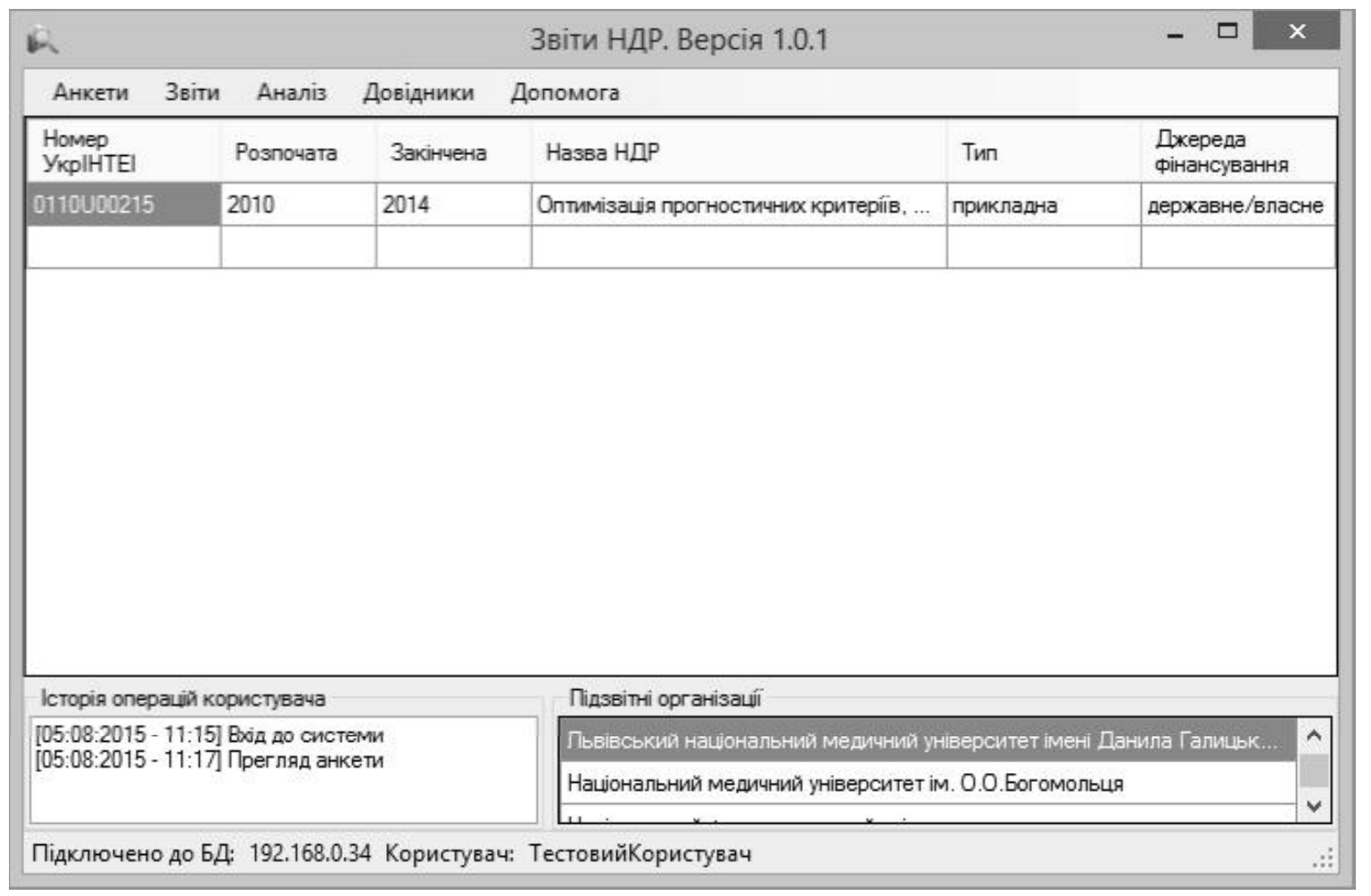

Рис. 7. Головна форма основного інтерфейсу додатку «Звіти НДР»

додаток «Звіти НДР». Для його реалізації використана програмна платформа Microsoft .Net Framework та мова програмування С\#. Для створення графічного інтерфейсу користувача використана технології Windows Forms [5]. Для вирішення завдання об’єктнореляційного відображення даних в додатку використано якісне ORM рішення для платформи .NET Framework технологія ADO.NET Entity Framework (EF) [6]. Для реалізації функцій безпеки використані вбудовані засоби аутентифікації та авторизації ОС Microsoft Windows, що забезпечують досить надійне функціонування. Розмежування доступу реалізовані через механізми групових політик, що дозволяє централізовано керувати ними за допомогою контролера домену на базі Microsoft Active Directory.

Додаток «Звіти НДР» багатокористувацький, тому якщо запуск програми здійснювався від імені облікового запису з роллю «Адміністратор», то головна форма додатку матиме вигляд показаний на рис. 6. Користувач із роллю «Адміністратор» уповноважений здійснювати настройку підключень до серверів електронної пошти і бази даних (вкладка «Підключення»).

Для автоматизації процесів отримання файлів-анкет за допомогою електронної пошти використовуються шаблони-відповіді, автоматично розсилати відправнику, при отриманні нового листа. Текст шаблонів так само може бути змінений з інтерфейсу адміністратора. Для розширення можливостей базового набору функцій в додатку використовуються зовнішні незалежно компільовані програмні модулі (плагіни). Їх підключення до базового інтерфейсу здійснюється на вкладці «Плагіни».

Якщо запуск програми здійснювався від імені облікового запису з роллю «Аналітик» або «Користувач», то буде запущений основний інтерфейс програми з головною формою наведеної на рис. 7.

Для завантаження анкет в меню «Анкети» може бути обраний бажаний спосіб завантаження файлів - анкет - з E-mail, $з$ файлу або вручну. При завантаженні анкети вручну буде запущено додаток «Анкета НДР» і результати будуть завантажені в базу без формування файла-анкети.

Для ролі «Аналітик» використовується такий же графічний інтерфейс, але набір функцій підтримують лише операції аналізу даних з меню «Аналіз». При цьому дані відображаються в деперсоналізованом вигляді.

Для динамічного розширення можливостей додатку «Звіти НДР» в ПЗ реалізовані механізми підключення плагінів - незалежно компілюємих програмних модулів. Основний додаток надає сервіси, що плагін може використовувати. До них відноситься надання плагіну можливість 
зареєструвати себе в основному додатку, а також надання протокол обміну даними з іншими плагінами. Основний додаток надає можливість адміністратору динамічно додавати і оновлювати плагіни без необхідності внесення змін в основний додаток. Для реалізації можливості динамічно підключати плагіни використовується вбудована в Microsoft .Net Framework технологія відображення (Reflection).

Висновки. 1. Потреба в прискоренні обробки інформації, отриманої при виконанні НДР, об’єктивізації та підтримки прийняття управлінських рішень щодо фінансування нових НДР призводить до необхідності наукового обгрунтування та побудови автоматизованої інформаційної системи обліку, моніторингу та прогнозування ефективності інноваційної діяльності.

2. До основних принципів, яким повинна відповідати спеціалізована інформаційна система планування, обліку та моніторингу інноваційної медичної інформації, відносяться принципи: системності, розвитку, сумісності, стандартизації та ефективності, безпеки даних та надійності, динамічності, наочності та інтуїтивного сприйняття користувачем, зручності у використанні та мінімального достатнього інформаційного забезпечення тощо.

3. Для реалізації функцій реєстрації, моніторингу та прогнозування інноваційної ефективності НДР обрано дворівневу клієнт-серверну архітектуру інформаційної системи. Для захисту інформації та розмежування доступу користувачів до окремих

\section{Література}

1. Закон України «Про інноваційну діяльність» від 04 липня 2002 року №40-IV, із змінами) - [Електронний pecypc]. - Режим доступу: zakon.rada.gov.ua/go/40-IV 2. Горбань А. Є. Обгрунтування необхідності створення та концептуальних принципів розробки автоматизованої інформаційної системи обліку та моніторингу інноваційної діяльності в сфері охорони здоров'я України / А. Є. Горбань // Клиническая информатика и Телемедицина. - 2015. - Т. 11, Вып. 12. - С. 5-12.

3. Рихтер Д. CLR via C\#. Программирование на платформе Microsoft .NET Framework 4.5 на языке C\# / Д. Рихтер. - СПб. : Питер, 2013. - 896 с. ресурсів інформаційної системи обрано модель рольового доступу.

4. Обрана для реалізації інформаційної системи на основі моделювання бізнес-процесів база даних складається з пов’ язаних таблиць. Для управління даними використовується РСУБД PostgreSQL, яка має достатній набор реалізованих функцій і порівнянна з кращими комерційними СУБД класу Oracle Database або Microsoft SQL Server.

5. При розробці додатку «Анкета НДР» було використано програмний інтерфейс Microsoft WinAPI і мова програмування $\mathrm{C}++$. Створений таким чином програмний додаток складається з єдиного виконуваного файлу і не вимагає для своєї роботи встановлення додаткових компонентів.

6. Для реалізації функцій збереження та обробки файлів - анкет НДР, аналізу отриманих даних і формувати відповідних звітів використовується програмний додаток «Звіти НДР», виконаний на програмній платформі Microsoft .Net Framework 3 мовою програмування С\#. Для створення графічного інтерфейсу користувача використана технологіï Windows Forms, для вирішення завдання об'єктно-реляційного відображення даних в додатку використано якісне ORM рішення для платформи .NET Framework технологія ADO.NET Entity Framework.

Перспективою подальших досліджень є розробка моделі прогнозу інноваційної ефективності НДР на етапі планування з використанням даних, отриманих за допомогою розробленої інформаційної системи.

4. Троелсен Э. Язык программирования С\# 5.0 и платформа .NET 4.5 / Эндрю Троелсен. - М. : Издательский дом «Вильямс», 2015. - 1312 с.

5. Фаулер М. Архитектура корпоративных программных приложений / М. Фаулер : Пер. с англ. - М. : Издательский дом «Вильямс», 2006. - 544 с.

6. Фаулер М. Шаблоны корпоративных приложений / М. Фаулер, Д. Райс, М. Фоммел и др. - М. : Издательский дом «Вильямс», 2010. - 544с. 